965). Identification of cultures of Hymenomycetes. Canadian fournal of 1139.

1. Color Standards and Color Nomenon D.C.: published by the author. 1914). Nigerian fungi: II. Bulletin of rmation, Kew 1914, 253-261.

[285]

Trans. Br. mycol. Soc. 81 (2) 285-290 (1983) Printed in Great Britain

\title{
PARAISARIA, A NEW GENUS FOR ISARIA DUBIA, THE ANAMORPH OF CORDYCEPS GRACILIS
}

\author{
BY R. A. SAMSON \\ Centraalbureau voor Schimmelcultures, P.O. Box 273, 3740 AG Baarn, The Netherlands \\ AND B. L. BRADY \\ Commonwealth Mycological Institute, Ferry Lane, Kew, Richmond, Surrey, TW9 $3 A F, U . K$.
}

The new genus Paraisaria is proposed for Isaria dubia. The entomogenous hyphomycete, frequently occurring on larvae of species of Hepialus (Lepidoptera, Hepialidae), is characterized shaped sympodially proliferating phialio of verticillately-branched conidiophores with flaskhyaline conidia in pealise to one-celled, hyphomycete is the anamorph of Cordyceps gracilis.

Isaria dubia was described by Delacroix (1893) on larvae of Hepialus lupulinus collected near Rouen, France. Delacroix compared the fungus with species of Clavaria and Thelephora, because he observed basidium-like structures with sterigmata. No type material seems to have been preserved, but during our studies on entomogenous fungi we have encountered several specimens which agree with the original descriptions and illustrations. Recently we also obtained two pure cultures, one grown from ascospores of Cordyceps gracilis Dur. \& Mont. Examination of Isaria dubia in vivo and in vitro showed that the species does not fit any hyphomycete genus and therefore the following new genus is proposed.

\section{Paraisaria gen.nov.}

Conidiophora hyalina synnematibus laxis pennatis coacta, repetite verticillata et verticillos terminales cellularum conidiogenarum ferentia. Cellulae conidiogenae phialidicae, lageniformes, saepe sympodialiter in $1-4$ collula proliferentes. Conidia continua, hyalina, levia, successione basipetali capitula mucida formantia. Genus entomogenum. Teleomorphosis Cordyceps $\mathrm{Fr}$.

Species typica Isaria dubia Delacr.

Conidiophores hyaline, with both verticillatelybranched and terminal whorls of branches and conidiogenous cells, aggregated into loose featherlike synnemata. Conidiogenous cells phialidic, flaskshaped, frequently sympodially proliferating to give rise to 1-4 phialide necks. Conidia one-celled, hyaline, smooth-walled, produced in basipetal succession in slimy heads. Entomogenous. Teleomorph: Cordyceps Fr.
Paraisaria dubia (Delacr.) comb.nov. Isaria dubia Delacr., Bull. Soc. Mycol. Fr. 9: 264
(1893), basionym.

Teleomorph: Cordyceps gracilis Dur. \& Mont. in Durieu, Fl. Alger. Crypt. 1: 449 (1846).

Larvae covered by pale yellow mycelium bearing several synnemata. The interior of the body white and chalky without resting spores. Conidiophores on the host hyaline, repeatedly verticillate, bearing either whorls of branches or of conidiogenous cells and aggregated into loose feather-like synnemata up to $10 \mathrm{~mm}$ long. Conidiogenous cells phialidic, $4-6.4 \times 2.4-3.2 \mu \mathrm{m}$, frequently sympodially proliferating, with a swollen venter giving rise to 1-6 sharply narrowed necks, $1.6-2.4 \times 0.8-1.5 \mu \mathrm{m}$. Conidia narrowly cylindrical to fusiform, onecelled, hyaline, smooth-walled, $3.2-4.8 \times 0.8 \mu \mathrm{m}$, produced in basipetal succession and aggregating in heads or fascicles.

Growth in pure culture obtained from either conidia or from germinating ascospores. Colonies on malt extract, oatmeal or Sabouraud maltose agar slow-growing, white to cream-coloured to pale yellow, velvety, forming several distinct synnemata after 2-3 weeks. Conidiophores, conidiogenous cells and conidia as on the host.

Teleomorph. The anamorph is often found growing alone on the host but also occurs in association with the teleomorph. The teleomorph was not observed in pure culture. It forms striking solitary stromata, 15-90 mm long, with a deep chrome yellow stipe terminating in a globose or ellipsoid capitate fertile region, 2-5 $\times 2-4 \mathrm{~mm}$, red or ochraceous, with numerous perithecial ostioles over the surface. According to Mains 
A
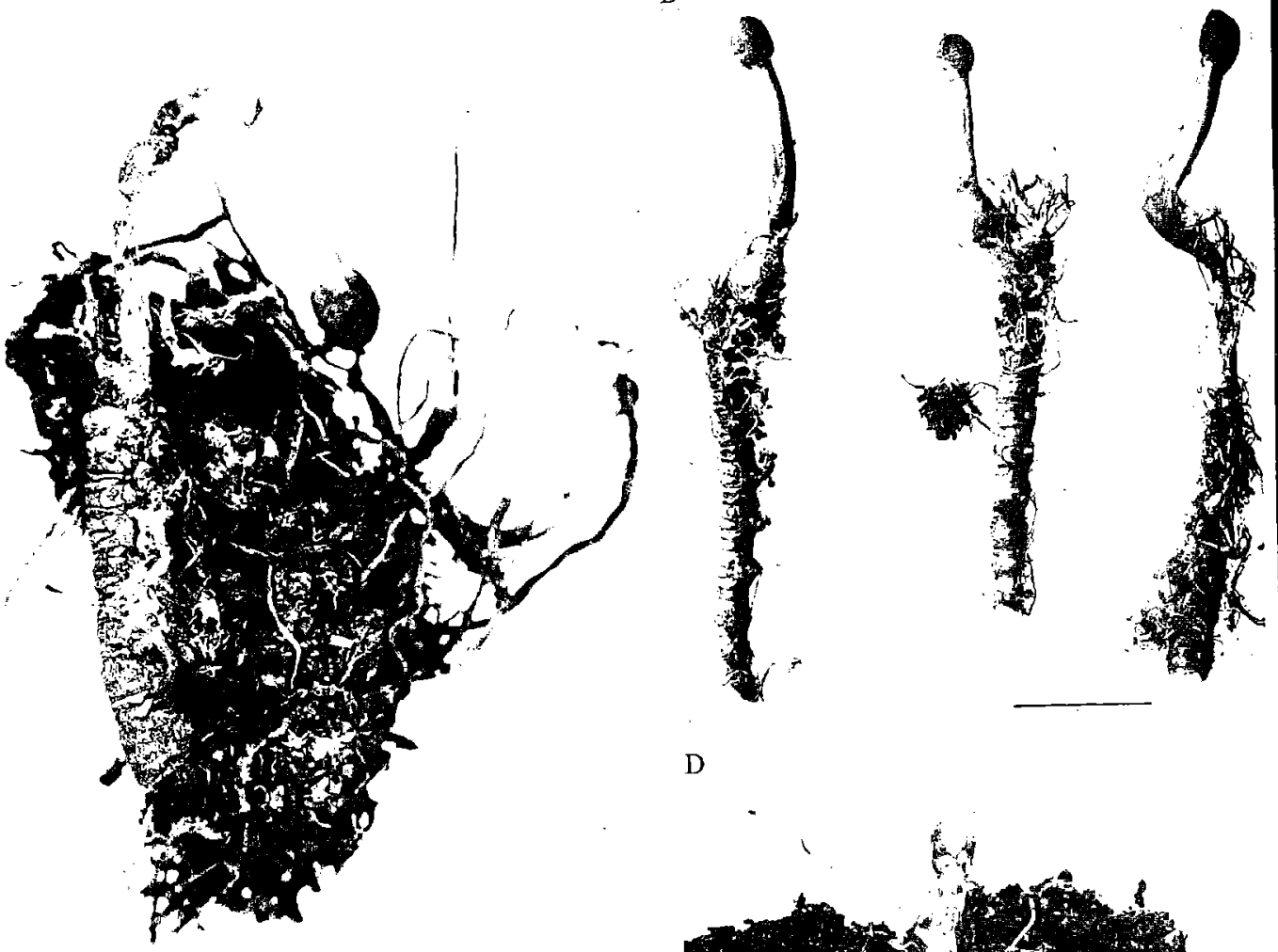

D
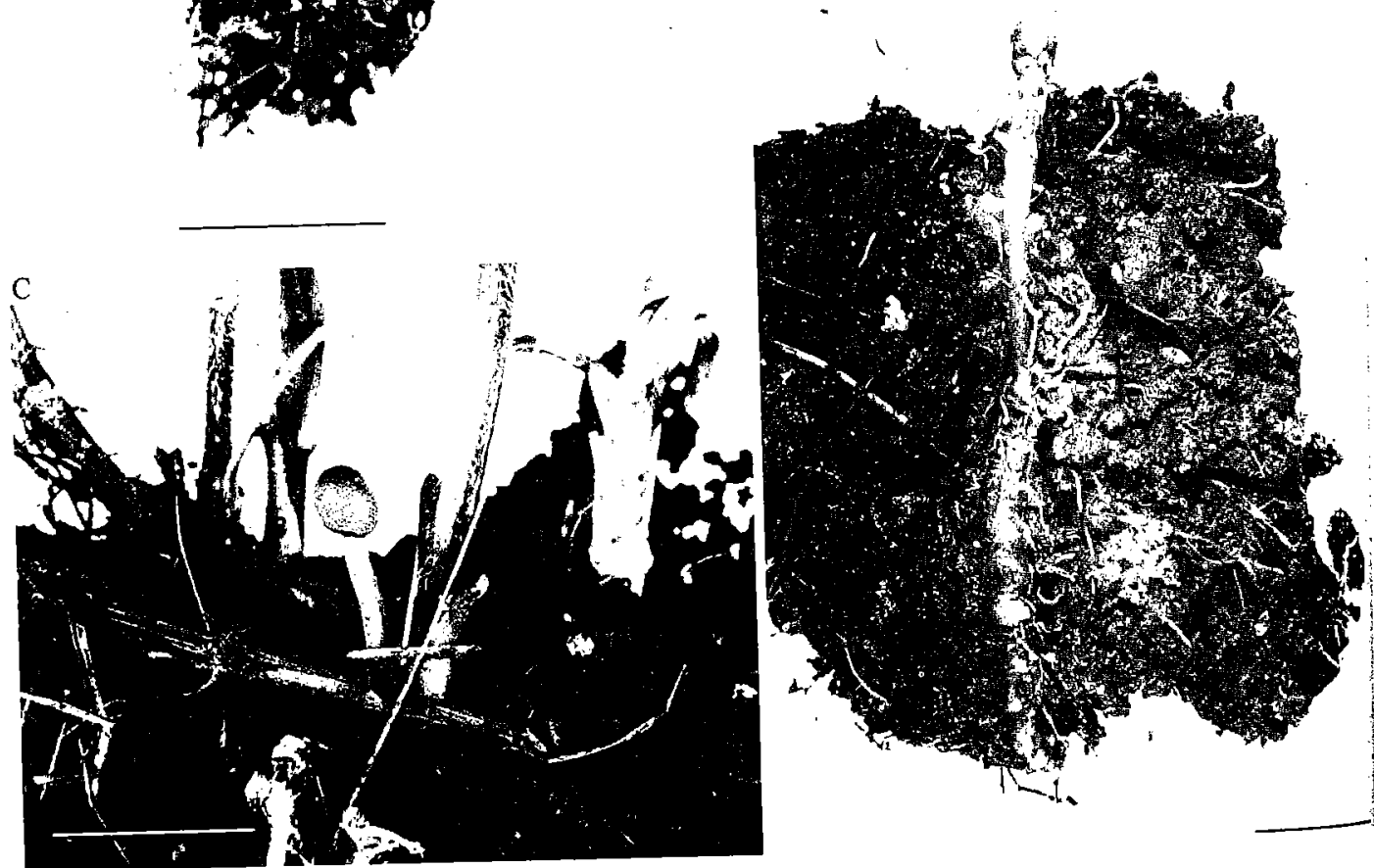

(1958)

$560-8$.

400-5:

septat

6-8x:

give tr

Spec

Herb

sp., $\mathrm{Hz}$ teleomı

states.

1947,

teleomi

sp., $3 \mathrm{~J}$

IMI 56

25 Mar

IMI 7:

Trefrev

IMI 80

Radnor

Dereha

Fig. 1. Cordycepsgracilis on Hepialus sp. (A) IMI 713. Both teleomorph and anamorph; (B) IMI 713, as above.

Copy of photograph at CMI, (C) IMI $16573(a)$. Copy of photograph, Rotham
Harpenden. Teleomorph in situ; (D) IMI $16573($ a). As above. Bars $=1 \mathrm{~cm}$.

R. E. E

Dereha

IMI 27

A. Frisl 

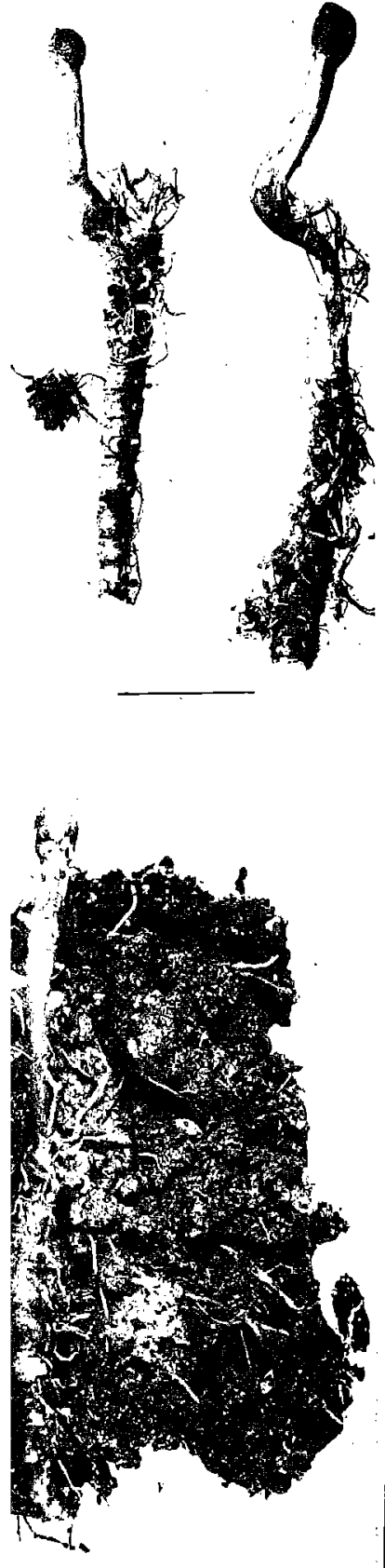

amorph; (B) IMI 713, as above zamsted Experimental Station,

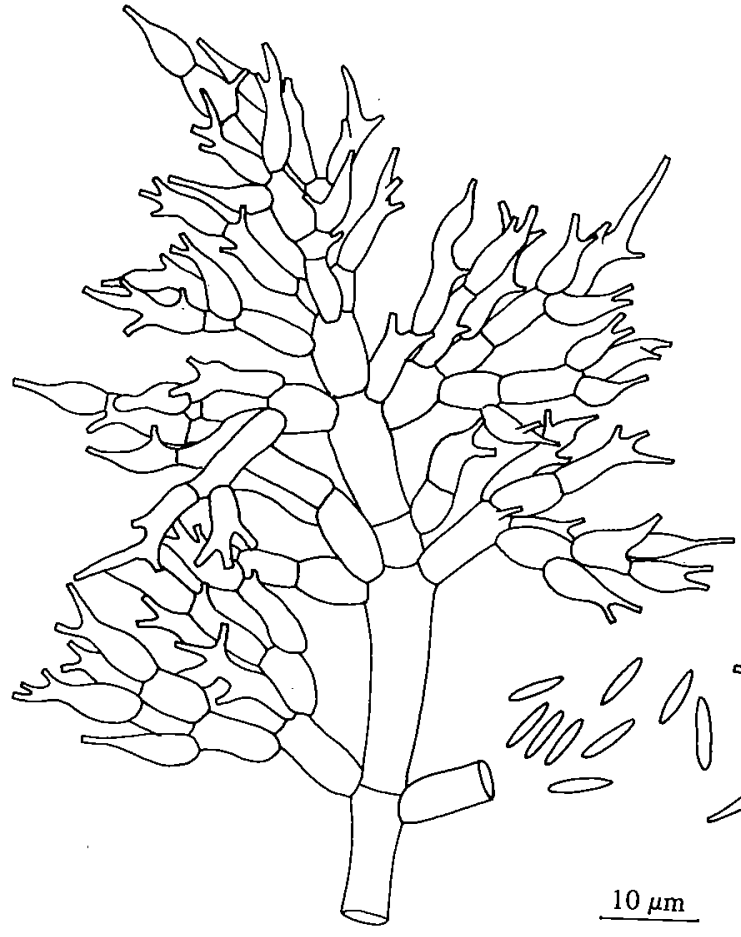

Fig. 2. Paraisaria dubia. Camera-ludica drawings of conidiophores and conidia.

(1958) 'perithecia are completely embedded, $560-840 \times 200-360 \mu \mathrm{m} ; \quad$ asci are cylindrical, $400-528 \times 4-6 \mu \mathrm{m} ;$ ascospores are filiform, multiseptate, breaking into one-celled fragments, $6-8 \times 1-1.5 \mu \mathrm{m}$.' These fragments germinate to give the anamorph.

Specimens examined:

Herbarium specimens (all on larvae): IMI 7.13 Hepialus sp., Harpenden, Herts., 5 Apr. 1945, A. Smith, mostly teleomorph but good photograph of material in both states. IMI 16573 (a) Hepialus sp., Harpenden, 16 May 1947, A. Smith (sent in by P. H. Gregory no. 727) teleomorph and anamorph (atypical). IMI 41601 Hepialus sp., 3 June 1950, C. J. La Touche, University of Leeds, teleomorph and anamorph on insect, with dried culture. IMI 56133 Hepialus sp., in ground at Heston, Cambs., 25 March 1954, T. J. Lagowski, not very good material. 73449 unidentified Lepidoptera, Nant Crafnant; Trefrew, N. Wales, 17 May 1958, J. Manners, teleomorph. Rad 80974 unidentified Lepidoptera, in bracken in soil, Radnor, 27 May 1960, G. M. Waterhouse and S. M. Dereham R.E. Evans Norfolk, March 1976 and 10 March 1977, Deresams, anamorph. IMI 214624 H. lupulinus, IMI 271635 Horfolk, June 1977, R. E. Evans, anamorph. A. Frisby, (sent in by sp., Ashford, Kent, 26 Apr. 1976.

\section{Living cultures:}

CBS $951.73=$ strain $90 / 73$, single ascospore isolate of Cordyceps gracilis made by E. Müller-Kögler, Darmstadt, F.R.G., from unidentified insect. CBS $680.77=$ strain $V_{54}$, isolated by N. Wilding from Hepialus sp., collected at Wye, Kent.

Since no holotype is available, IMI 41601 is here indicated as neotype of Isaria dubia.

\section{DISCUSSION}

Recently Lauritzen (1971) and Laessøe (1982) described Cordyceps gracilis from Norway and Denmark respectively with the Paraisaria anamorph as a typical species on Hepialus larvae.

The genetic association of $P$. dubia with Cordyceps gracilis has also been suggested by Petch (1932), Favre (1942), Kobayasi (1941) and Mains (1958). The strain CBS 951.73 grown from single ascospores confirms these earlier observations.

In the genus Isaria Pers. about 200 heterogeneous taxa have been included which belong more satisfactorily in various other hyphomycete form genera. Von Arx (1970) redefined Isaria, proposing
I. felina (DC.) Fr. as the lectotype species. 


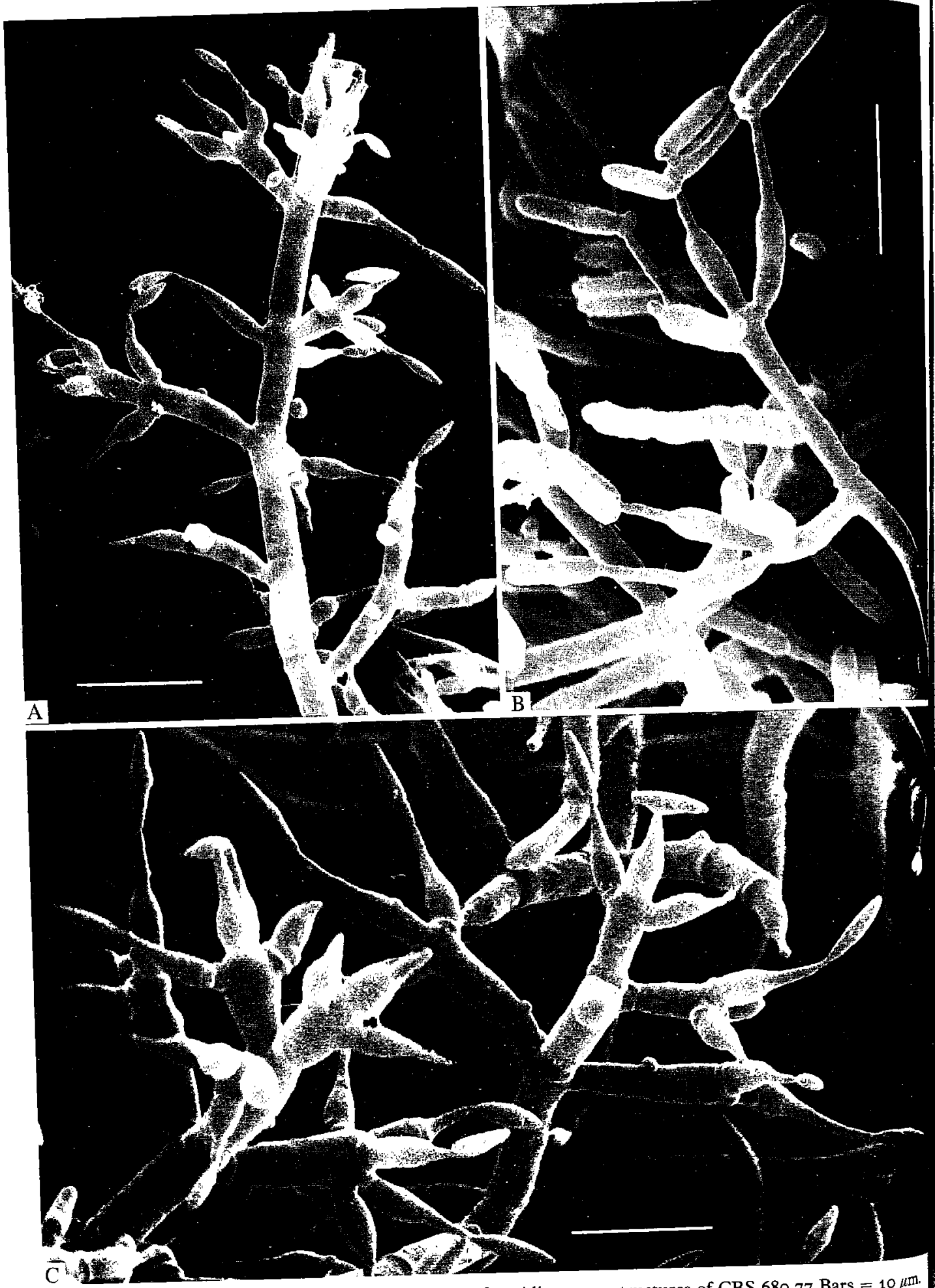

Following this , Höhnel (= Beau Evans, 1982) wa: When the history clear that $I$. ag ، species sanctionc thus represents $t$. by Gams (1971: then coincides $w$ Isaria has alsc (e.g. Clements , Holm: Fr. Howe Paecilomyces var phialidic species Lebert (= Insect Hirsutella Pat. ( 1973). Isaria $d$ suitably in any because it combil frequently symp shaped phialides

Paraisaria bea cladium Petch (1c on a spider. In a 1 two more species monium cleoni $\mathrm{Wi}$ both produce sc genus Sorosporel. Petch (1942) ha masses in the typt sclerotial mass mi of the spider wa: The only extant which is poorly Stilbella-like fun hymenium-like f specimen, IMI : sp. on Agriotes sp ciated with Soro: this specimen anc $S$. cleoni. The sf contains Sorospor nemata with con those described 1 sporella uvella $(\mathrm{K}$ In herb. $\mathrm{K}$ a s] intricatum, is presı anxia Lec.) whicl Speare $(1.917,192$ on several specie: specimen contai mycelium and 1 considered this tc state' of Sorosp. studies however, suggestions.

The conidioger.

micrographs of conidiogenous structures of CBS 680.77 Bars $=10 \mu \mathrm{m}$ 10 


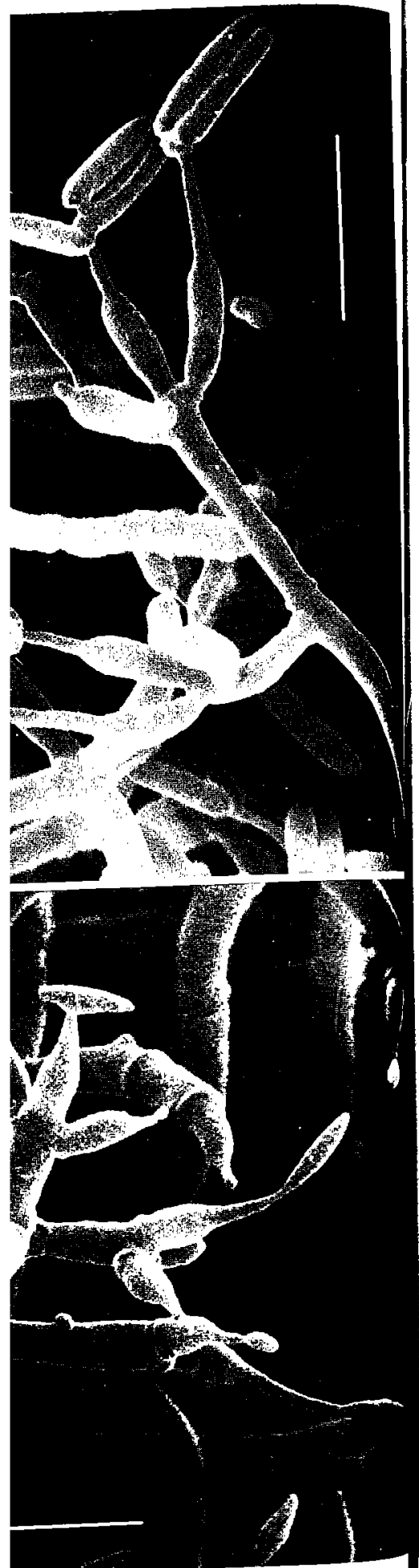

structures of CBS 680.77 Bars $=10 \mu \mathrm{m}$
Following this concept of the genus $I$. amorpha Höhnel ( = Beauveria amorpha (Höhnel) Samson \& Evans, 1982) was also accepted by de Hoog (1972). When the history of Isaria is traced back it becomes clear that $I$. agaricina Pers. is the only original species sanctioned by Fries (1832), and this species thus represents the holotype of the genus. As stated by Gams (1971: 141 foot-note) the genus concept then coincides with that of Tilachlidium Preuss.

Isaria has also been typified by several authors (e.g. Clements \& Shear, 1931) with I. farinosa Holm: Fr. However this species is congeneric with Paecilomyces variotii Bainier (Samson, 1974); other phialidic species are classified in Akanthomyces Lebert (= Insecticola Mains), Gibellula Cavara or Hirsutella Pat. (Mains, 1950; Samson \& Evans, 1973). Isaria dubia cannot be accommodated suitably in any of the above-mentioned genera, because it combines verticillate conidiophores with frequently sympodially-proliferating truly flaskshaped phialides and conidia in heads.

Paraisaria bears some resemblance to Syngliocladium Petch (1932), based on $S$. aranearum Petch on a spider. In a later paper, Petch (1942) proposed two more species, $S$. cleoni (Wize) Petch (=Acremonium cleon $i \mathrm{Wize}$ ) and $S$. intricatum Petch, which both produce sclerotial masses of the anamorph genus Sorosporella Sorok. within the insect body. Petch (1942) had not observed these sclerotial masses in the type species, but he suggested that the sclerotial mass might have fallen out, since the body of the spider was broken before it was collected. The only extant type specimen of $S$. aranearum, which is poorly preserved, contains a stipitate Stilbella-like fungus with phialides arranged in a hymenium-like pattern. In herb. IMI there is a specimen, IMI 27578, labelled: 'Syngliocladium sp. on Agriotes sp. (collected by H. C. Gough) associated with Sorosporella'; Petch (1942) examined this specimen and based on it his new combination $S$. cleoni. The specimen is in poor condition but contains Sorosporella-like resting spores and synnemata with conidiogenous structures similar to those described by Speare $(1917,1920)$ as Sorosporella uvella (Krass.) Giard.

In herb. K a specimen, labelled Syngliocladium intricatum, is preserved on a whitegrub (Phyllophaga anxia Lec.) which is also similar to the specimens Speare $(1917,1920)$ described as Sorosporella uvella on several species of cutworm in the U.S.A. The specimen contains much external pale yellow mycelium and loose synnemata. Petch (1942) considered this to be the Syngliocladium 'conidial state' of Sorosporella uvella. Without cultural studies however, it is difficult to confirm his suggestions.

The conidiogenous structure of Paraisaria bears 10 some resemblance to two other phialidic genera: Sesquicillium W. Gams and Tolypocladium W. Gams. In Sesquicillium the conidia are, however, produced in dry imbricate chains on pairs of a terminal and subterminal phialide. In the Beauverialike genus Tolypocladium the conidia are produced in heads, and the clustered phialides which proliferate rarely have only a thin short neck. Although we have encountered $T$. cylindrosporum W. Gams on insects on a few occasions, we have never observed synnematous development.

Granulomanus aranearum (Petch) de Hoog \& Samson (de Hoog, 1978) is superficially reminiscent of Paraisaria. This fungus is a synanamorph of Torrubiella, frequently occurring with the anamorph Gibellula. The conidiophores of Granulomanus are undifferentiated, while the phialides bear some conidiiferous protrusions. The conidia are singlecelled, but not produced in heads.

The authors wish to thank Dr N. Wilding, Dr S. Mardell, Dr E. Müller-Kögler and Mr R. E. Evans for sending material of Isaria dubia. $\mathrm{Dr}$ W. Gams kindly provided the Latin description.

\section{REFERENCES}

ARx, J. A. voN (1970). The Genera of Fungi Sporulating in Pure Culture. Lehre, J. Cramer.

Clements, F. E., \& Shear, C. L. (1931). The Genera of Fungi. New York, Wilson \& Co.

Delacroix, G. (1893). Travaux du Laboratoire de Pathologie Végétale. Bulletin de la Société Mycologique de France 9, 260-268.

Favre, J. (1942). Le Cordyceps gracilis Greville en Suisse. Complément et rectification. Schweizerische Zeitschrift für Pilzkunde 20, 123-124.

FrIEs, E. M. (1832). Systema mycologicum, sistens fungorum ordines, genera, et species 3, Lund, Griefswald.

GaMs, W. (1971). Cephalosporium-artige Schimmelpilze (Hyphomycetes). Stuttgart, Gustav Fischer Verlag.

Hoog, G. S. DE (1972). The genera Beauveria, Isaria, Tritirachium and Acrodontium gen.nov. Studies in Mycology, Baarn 1, 1-41.

Hoog, G. S. DE (1978). Notes on some fungicolous Hyphomycetes and their relatives. Persoonia 10, 33-81.

KoBAYASI, Y. (1941). The genus Cordyceps and its allies. Science Reports of the Tokyo Bunrika Daigaku, Section B (84), 53-260.

LAEssøe, T. (1982). Snyltekølle (Cordyceps (Fr.) Link) i Danmark. Svampe 6, 73-83.

LAURITZEN, E. M. (1971). Cordyceps gracilis Montagne \& Durieu ny for Skandinavia. Blyttia 29 (2), 85-87.

MaINs, E. B. (1950). Entomogenous species of Akanthomyces, Hymenostilbe and Insecticola in North America. Mycologia 42, 566-589.

MaINS, E. B. (1958). North American entomogenous species of Cordyceps. Mycologia 50, 169-222.

PETCH, T. (1932). List of entomogenous fungi of Great Britain. Transactions of the British Mycological Society $17,170-178$. 
PETCH, T. (1942). Notes on entomogenous fungi. Transactions of the British Mycological Society 25, 250-265. act (1974). Paecilomyces and some allied hyphomycetes. Studies in Mycology, Baarn 6, 80-85. hyphom SAMSON, R. A. \& EvAN, Ghana I. The genera Gibellula and genous fungi from Ghana 1 . The generica 22,522-528. Pseudogibellula. Acta Botanica Neerlandica 22, Two Beau- veria spp. from South America. Fournal of Invertebrate Pathology 39, 93-97.

SPERE, A. T. (1917). Sorosporella uvella and its occurResearch 8, 189-194.

SPEARE, A. T. (1920). On certain entomogenous fungi. Mycologia 12, 62-76. rence in cutworms in America. fournal of Agricultural

Trans. Br.

$$
\text { TF }
$$

(Received for publication 18 November 1982) 